\title{
Devotional Mysticism: An Analogical Study of Hafez-e Shirazi and William Blake
}

\author{
Muhammad Hussein Oroskhan \\ Department of English Literature, Faculty of Foreign Languages, Shiraz University, Shiraz, Fars, Iran
}

\begin{abstract}
Mysticism is a method of thinking not wildly shared by the majority of the people around the entire world whereas unique individuals sap at the roots of this concept. Less a coherent movement than a way of thinking, the concept of mysticism is not systematically defined as a firm set of ideas but is more tended to be shaped by the individuals dealing with this concept. In this respect, each person carries this notion in his further exploration on his own accord since the concept is highly individualistic. As such, William Blake directed the concept toward a sort of devotional mysticism emphasizing on the individual's hard effort in achieving unity with God. In a similar manner, Hafez-e Shirazi, a classical Persian poet, undertook more or less the same method in signifying the notion of mysticism to his further investigations in his poems. Hence, through this paper, an attempt is made to explore the poems of these two poets regardless of their different cultural and geographical backgrounds to prove that each poet more or less has applied the same method called devotional mysticism in achieving unification with God. Moreover, the aforementioned research is based on the theoretical framework of comparative literature propounded by Francoise Jost and developed and expanded by Shunqing Cao in their seminal works on comparative literature.
\end{abstract}

Index Terms — comparative literature, analogical study, devotional mysticism, Hafez-e Shirazi, William Blake

\section{INTRODUCTION}

Human being as a creature with finite capacity tries to connect him/her self with the absolute because in that sense he/she is capable of justifying his existence within this great and unlimited universe. To reach such platform in which the human being is able to find unification with God, the human being should experience some especial relationship with the universe which is beyond the concept of reasoning and thought. This unusual relationship is called mysticism. In other word, "Mysticism is the endeavor of humans to apprehend Reality and experience the ecstasy of being in communion with God, by means of personal revelation, transcendentalism and contemplation or meditation on the Divine" (Samantaray, 2013, p. 41). Those human beings experiencing the ecstasy of being in a close relationship with God are called mystics. In this definition having a close relationship with God is highlighted as the most important feature, however achieving such status is not a well-trodden path. Indeed, the path ending with such an exhilarating moment is filled with different stages of difficult moments for the individual to pass on and finally see him/herself in communion with God. Searching the line of literature within the scope of different geographical areas, one can find common grounds while considering how mysticism works under similar trends that can be called devotional mysticism.

In this regard, through this study, it is tried to explore the works of two distinct authors from different geographical and cultural background to see to what extent these two authors are sharing a common perspective for considering their mystic life. Nonetheless, it should be noted that before embarking on such investigation, a reliable framework should be provided to better illustrate the works of these two authors. Therefore, the theoretical basis of comparative literature is applied to show the extent to which two different authors can be compared together. As such, Jost's basic definition of comparative literature is pondered on and expanded by other theorists to provide the suitable framework necessary for our discussion. Hence, it is tried to use the methods of comparative literature and simultaneously applying the concept of devotional mysticism within this defined framework to arrive at a platform suitable for conducting an analogical study between the works of William Blake and Hafez-e Shirazi. Finally, it is proved that though these two poets are from different cultural and historical background, they a share a common point of view in exploring their perspective toward the eternal world.

\section{COMPARATIVE Literature}

The theoretical basis of this paper is depended on an often used term 'comparative literature'. According to Siegbert Salomon Prawer, the concept of comparative literature can be studied as an "examination of literary texts in more than one language, through an investigation of contrast, analogy, provenance or influence; or a study of literary relations and communications between two or more groups that speak different language" (Prawer, 1973, p. 8). Though Prawer's definition of comparative literature is self-explanatory enough for providing a basic platform for the critics to commence their exploration of this field, François Jost, who is a well-known comparative literature critic, has far better and minutely categorized the whole realm of comparative literature by providing a basic categorization of this field into four groups of "influences and analogies; movements and trends; genres and forms; motifs, types and themes. (Jost, 
1974, p. 33). These basic fields of comparative literature categorized by Jost cannot be sharply demarcated; however, the main focus of comparative studies has been yielded by the first branch, such that influences and analogies play the central role as far as the objectives of the discipline are concerned; "influences and analogies have often been considered the two sole objectives of the discipline. In fact, in a sense, comparative literature be reduced to a study of relationships in terms of influence or analogy" (ibid). Moreover, Jost besides categorizing the first group as the most important one, also distinguishes between the role of influence and affinity by giving priority to the second type; "comparatives believe that affinities are better than direct influences for proving the fundamental homogeneity of a particular civilizations and the literary intelligence common to all national elites" (p. 37). In his justification for giving priority to the role of affinity over the role of influence, he states that:

In a sense, such studies (analogy) yield richer, more substantial results that influence studies, for the latter can at best reveal particular relations between specific works, whereas the former (influence studies) more frequently suggest conclusions regarding aesthetic or philosophical attitudes in general. (p. 38)

Shunqing Cao in his seminal work on comparative literature entitled The Variation Theory of Comparative Literature, more elaborates on this notion of analogy within the whole concept of comparative literature. His analysis which leads to the high stance of analogy studies in the concept of comparative literature lies in the simplicity of this method in exploring different works of literature from different countries. This means any work of literature from any place around the world can be considered to be studied in a parallel way to explore the common and different parts of each work and then concludes by finding a certain platform to put both works together:

The key point for analogy study is to find the same and different points as well as their relationship which means to uncover certain relationships among the similarities and discover the similarities among the differences or among seemingly unrelated literary phenomena to find certain relationship on the certain aspects of ideological concept or structure. (2016, p. 65)

Cao's firm establishment of analogy studies as the basis of comparative literature leads him to more elaborates on this concept by categorizing it into different groups; "analogy study generally includes several categories such as typology, comparative poetics, thematology, genealogy, and interdisciplinary research" (p. 68). Cao's categorization of analogy study better highlights and clarifies the concept of analogy study which was never fully investigated in Jost's explanation of this concept. Besides, he explains each section thoroughly to portray the whole picture of analogy study. His elaboration on the notion of typology leads him to theorizes how two literary works from different cultural backgrounds produce a more or less same result, even when each work is also situated in a different age;

The research goal of typology is to compare similar literary phenomena produced in different space-time cultural backgrounds, to search out general rules and laws of the thorough process of literary evolution, and meanwhile to discover the deep level cultural differences under the similar type representation. (p. 68)

\section{DeVotional Mysticism}

An assumption is underlying human life on earth that human beings are constituted of faculty of thinking directed toward their possible aims. The inevitable acceptance of this fact underpins the point that human beings take steps with regard to their faculty of thought. Nonetheless, human being's actions are not always led toward their desirable aims. A certain moment that leaves human being befuddled is the time when he/she tries to find his/her own ways toward God. The broad faculty of reasoning never eases the path of human beings in achieving this certain goal. Unavoidably, he/she needs to search other possible existing ways for arriving at his/her goal away from the path of reasoning which is within the framework of thinking. Not a certain notion to be easily categorized, the word 'mysticism' has been labeled to cover this broad and ambiguous realm of ideas which is devoid of any simple reasoning. As such, "to the mystic, whether he be philosopher, poet, artist, or priest, the aim of life is to become like God, and thus to attain union with the Divine" (Spurgeon, 2011, p. 5). Clearly the point which carries significance here is that arriving at a position in which the human being can find him/her self while forming a close union with God is of utmost importance regardless of the possible methods of performing the task. This shows that "Mysticism is, in truth, a temper rather than a doctrine, an atmosphere rather than a system of philosophy" (4).

The aforementioned definition clears the unclear realm of mysticism by attesting to the fact that the concept of mysticism is not a categorized theory situated within a specific framework whereas this concept is endowed with ambiguous realm forever. Any individual dealing with this concept should undertake this prominent feature of mysticism that he/she is situated within a world in which no one can clearly finds his path and therefore each person tries to see into the world and make a connection with God. Dissolving himself within the external world, the mystic finds an internal way within himself to reach the Almighty and shows his unjustifiable path in terms of reason to the people around the world:

The mystic is somewhat in the position of a man who, in a world of blind men, has suddenly been granted sight, and who, gazing at the sunrise, and overwhelmed by the glory of it, tries, however falteringly, to convey to his fellows what he sees. (p. 5)

As it is shown, the mystic is a special person with a unique vision seeing into the world searching for common reality beyond the superficial appearance of the world. In this regard, the mystic attaches everything in this world together to form a unity basing God at the center; "the true mystic then, in the full sense of the term, is one who knows there is 
unity under diversity at the center of all existence"(p. 6). Mysticism capitalizes the unity beyond the whole world as the only method of apprehending the notion of God. Based upon this assumption, their highest goal is seeing not only into the whole world but seeing so as to be unified with God. In this respect, "their highest consummation it is the supreme adventure of the soul: to use the matchless words of Plotinus, it is "the flight of the Alone to the Alone" (p. 7). Since the unification with God is greatly emphasized, some critics call this type of mysticism as devotional mysticism; "these are the devotional mystics who make use of nature and of the experiences of common life with perfect freedom and naturalness as allies of their thoughts of God and of their desire to find Him" (Macnicol, 1961, p. 213).

\section{Devotional Mysticism in William Blake}

For a poet who claimed that "I must create my own system or be enslaved by another man's" (Blake, 2008, p. xi), the concept of mysticism is most suited. William Blake established a whole new system of writing poetry for himself. Born in 1757, Blake is considered among the first generation of English romantic poets. He never had the chance to educate himself by attending schools and colleges of his time, but had the extraordinary gift of artistic skills. Besides that, he had vision of seeing into the things around himself which led him ultimately in comprehending God around himself:

At the age of four he saw God looking in at the window, and from that time until he welcomed the approach of death by singing songs of joy which made the rafters ring, he lived in an atmosphere of divine illumination. (p. 93)

His vision compelled him forward to connect with the extraordinary world; to search for God in the existence of the world. Such a unique vision accepts no boundaries and limitations on human actions which are directed toward the Almighty. Indeed, the subject sees no barrier other than the existence of God before him. Blake is also propagating the same view by justifying the ways of human being while being devoid of any barrier. This means that human's inquiry to beseech the presence of God overshadows the hindrance of any obstacle. In this respect, the human being desiring the presence of God should have an extraordinary comprehension of the world accompanied by the element of love; respectively these two collaboratively working together can soar up human being into a different realm of understanding not at all accessible via the rules and regulations of the society of human beings. As such, "In Blake's view the qualities most sorely needed by men are not restraint and discipline, obedience or a sense of duty, but love and understanding (Spurgeon, 2011, p. 45)".

To open the Eternal Worlds, to open the immortal Eyes

Of Man inwards into the Worlds of Thought: into Eternity

Ever expanding in the Bosom of God, the Human Imagination .

O Saviour pour upon me thy Spirit of meekness \& love

Annihilate the Selfhood in me, be thou all my life !

Guide thou my hand which trembles exceedingly upon the rock of ages, (Blake, 2008, p. 147)

Subduing reason for the sake of love and comprehension of the world puts the human being outside of the domain of society. Generally speaking, for analyzing the life of a man, one needs to probe the structure of society first and then examines its impact on the individual or to consider to what extent the human being is following the rules and regulations of the society. Nonetheless, when a mystic is neglecting the society as the source of unnecessary rules and regulations in achieving the unity with God, the mystic cannot live in vacuum but should search for a context more suited to his situation. As such, nature affords a suitable shelter for the mystic who is in search of a place devoid of any obstacles and barriers for unifying with God. No doubt that Blake as a romantic poet followed the same method so as to reach his thoughts. Therefore, "Blake uses Nature to illustrate its direct correlation to both man and the Creator" (Samantaray, 2013, p. 47). In The Echoing Green, Blake astonishingly expresses this view;

The sun does arise,

And make happy the skies.

The merry bells ring

To welcome the spring.

The skylark and thrush,

The birds of the bush,

Sing louder around,

To the bells' cheerful sound,

While our sports shall be seen

On the echoing green. (Blake, 2008, p.11)

Blake's visionary experience needed two primary requisite before fully being expressed. Firstly the poet needs to be thinking totally out of the context of society. This meant that the rules and regulations dominating the society are considered by the poets as the hindrance not a path-maker helping the mystical poet achieving his aim. Secondly, once the mystical poet is dispensed with the society, it is upon his/her shoulder to search for a new place which aptly matches his/her aims. And as the nature is selected as the primary source of inciting great ideas in the mystic's mind, the mystic is undertaking a new role as a visionary person seeing into the things around the world. For Blake being a visionary poet is of prime importance because once the individual is endowed with a vision, he/she is able to release him/her self from the boundaries and limitations of this world and sees him/herself more close to God that ever. As such, "Blake has 
explained very carefully the way in which the visionary faculty worked in him (Spurgeon, 2011, p. 138)". In his letters, he elaborates on this notion of vision as follows:

What to others a trifle appears

Fills me full of smiles or tears;

For double the vision my Eyes do see,

And a double vision is always with me.

With my inward Eye, 'tis an old Man grey,

With my outward, a Thistle across my way. (Blake, 2008, p. 721)

For Blake gaining a vision is the last step before being fully unified with the God. In defining the concept of devotional mysticism, the point which was highly emphasized was the unification of the person with God. Indeed, the person in the path of devotional mysticism yearns for a new realm of reality that is experienced by coming close to God far beyond the usual sense of understanding. This carries a great significance for Blake since it is shown that human being is indeed a small part of the great God but only distanced from him by being situated in this world; "he identified God with Man in order to show that all human beings have a divine element within themselves" (Samantaray, 2013, p. 44). In his Everlasting Gospel, he beautifully expresses his final achievement of a new realm of reality in which the man has grown extremely close to God; "If Thou Humblest Thyself, Thou humblest Me/Thou also dwell'st in Eternity/Thou art a Man: God is no more/Thy own Humanity learn to adore/For that is My spirit of life" (Blake, 2008, p. 161).

\section{Devotional Mysticism As Mystical Sufism in HaFeZ-e ShiRaZI}

As a classical Persian poet, Hafez's poems are frequently read by Persians to the extent that Dick Davis, a famous well-known translator of Persian poems into English language, has pointed that Iranians may neglect reading Quran but never Hafez's Divan (2013, p. 7). Undoubtedly, Hafez's stature is endowed with a great stature among the Iranians along all these years. Hafez used to write in the form of ghazal which "expresses the never-changing human emotions, love, sufferings, longings, hope, and despair" (p. 23). Seemingly, Hafez has undertaken the same steps as William Blake has taken in reaching unity with God. Clearly, each poet belongs to a specific era and different country; one living in the east in the eleventh century, the other poet living in the literary era of English romanticism in eighteenth and nineteenth century. Nonetheless, one can trace the same line of thought in each poet resulting in the discovering of a new realm of reality understandable through the terms of mysticism. Interestingly, the label of devotional mysticism that was used for explaining Blake is not the same as the one used by the interpreters of Hafez to describe his poems. Instead, critics have used the Sufism as the suitable term for describing Hafez's mysticism:

The term Sufism that first appeared in the nineteenth century, or tasavvof, as it is known in the Muslim world, is a mystical movement within Islam that seeks to find the truth of divine love and knowledge through direct personal experience of God. (Schimmel, 2017, p. 33)

Though, the context in which Hafez is writing is totally different from Blake but more or less, a common ground can be found between them. Hafez's mystical movement is more tended toward Sufism which is an Islamic term for the description of mysticism. However, the aim of experiencing the truth of divine love as being prioritized above any other entity is almost the same as Blake's devotional mysticism. As such, the same stages leading to devotional mysticism already investigated in Blake can be studied here in Hafez. The primary stage unfolded by Blake in his path of achieving a close companion with God began by one's purging himself of the realm of reason so as to grasp the chance of entering the domain of love and comprehension. For Hafez as it was for Blake, the concept of love is beyond reasoning and an individual can only achieves the eternal realm of God's presence when he is in close connection with the concept of love and compassion. As such, Hafez expresses his view regarding the priority of love over reason as follows; "The holy court of love is a thousand times higher/ Than the house of reason/Only a man who holds his soul/Lightly on his sleeve can kiss the threshold of that court" (Hafez, 1995, p. 123). Hafez's last words are the ones describing a new gathering not ruled by the laws of society whereas describing a new company of men created in which the rules and regulations of the society are not applicable and the human being is governed by the power of love. Once the basic foundation of a new gathering is firmed, the mystic tries to use the power of love to connect with anything in nature. In this respect, Hafez imagines himself infinitely close to each and every element in nature:

Tell me of squirrels and birds you know.

Awaken your legion of nightingales -

Let them soar wild and free in the sky

And begin to sing to God.

Let's all begin to sing to God! (p. 188)

In a similar way as Blake, Hafez has firmly established the two requisites of devotional mysticism. First, these two include the attempt of distancing oneself from the rules and regulation of the society and then the experience of having a close association with the nature as the possible source of reaching God. Once the mystical poet has arrived at such a situation, he/she has reached a level in which he/she is able to experience the unique vision of seeing beyond the usual category of this world. Though, Hafez's unique vision of seeing beyond the material world is colored with Islamic philosophy but still carries the same notion as Blake's extraordinary vision of seeing the truth: 
What can I tell you? Last night at the tavern,

When I was drunk and ruined, what glad news

Did Gabriel bring from the invisible world?

"Your perch is on the lote tree in Paradise,

$\mathrm{Oh}$, wide-seeing hawk, what are you doing

Crouching in this mop closet of calamity? (p. 197)

Hafez has used Gabriel who is God's messenger to show his closeness with God. Hafez has clearly showed that one's ideal desire is to derive forward the human being more close to God. His main task is to arrive at such a moment in which he can see the truth of life. Though, it may seem a difficult task for the normal people, Hafez has seemingly achieved this revealing moment. In fact, Hafez himself claimed that he had deciphered and conveyed the ultimate meaning; "Nobody has lifted the veil from the face of inner meaning like Hafez/Ever since one arranged the curls of bride speech" (Schimmel, 2017, p. 25). Truly, Hafez has skillfully drawn together a masterpiece which has fascinated the people ever since and showed the truth path of achieving unity with God. Macnicole in his attempt to define devotional mysticism has mentioned that "devotional mystics make use of nature and of the experiences of common life with perfect freedom and naturalness as allies of their thoughts of God and of their desire to find Him" (1961, p. 213). Based upon his definition of devotional mysticism, Hafez can be considered a prototype achieving such status by trying to find the inherent truth in nature:

Hafez focuses on inherent truth:

Oh, ascetics, go away. Stop arguing with those

Who drink the bitter stuff, because it was precisely

This gift the divine ones gave us in Pre-Eternity.

Whatever God had poured into our goblet

We drank, whether it was the wine

Of heaven or the wine of drunkenness. (Hafez, 1995, p. 235)

\section{CONCLUSION}

Through this paper, a comparative study was conducted between William Blake and Hafez-e Shirazi. This should be noted that the aforementioned study which was conducted between Blake and Hafez was not based on the determination of the side influencing the other side as the usual method of comparative studies in literature whereas it was tried to search for the common points of comparison existing between these two authors. Considering the geographical and cultural background of Hafez and Blake, no common point was discovered to be deemed as the suitable platform for our further study between these two poets. Therefore, the analogical framework of comparative study was applied and fitted with the concept of mysticism. As such, each author's line of thought was measured with regard to the concept of mysticism and finally a common ground was reached between these two authors to conduct a comparative study between these two poets.

Capitalizing the role of mysticism as the bridge between the two poets needed further elaboration of the term mysticism itself. To explain what was meant by mysticism, the term mysticism was further attached with the word devotional to add a new dimension to the concept of mysticism. By adding this word to the original concept of mysticism, an attempt was made to pre-empt the concept of human's unification with God as the prime importance in the. In this regard, the defined concept of mysticism was unfolded based on four stages ending in human's unification with. The first two stages which are preliminary to the upcoming ones include the moments in which the mystical poets needs to get rid of the rule and regulations of the society and creates a new haven for him/herself. The mystical poet is always believed to leave the awkward realm of the cities for some joyful and peaceful moments in nature. Once the poet is totally settled in nature, he creates a unique vision to enable him/herself to see the inherent truth in nature and ultimately feels close to God. The above discussion proved that both Blake and Hafez though coming from different geographical and cultural background shared a common ground as a new realm of reality proposed by each author in reaching and uniting with God that is commonly named as mysticism, nevertheless, these two poets experienced a different stage of that called devotional mysticism.

\section{REFERENCES}

[1] Blake, W., \& Fuller, D. (2008). William Blake: Selected Poetry and Prose. Harlow, England: Pearson Longman.

[2] CAO, S. (2016). Variation Theory of Comparative Literature. Place of publication not identified: SPRINGER.

[3] Davis, D., H., Al-Dīn, ' Z., \& Khātūn, J. M. (2013). Faces of love: Hafez and the Poets of Shiraz. New York: Penguin Books.

[4] Jost, F. (1974). Introduction to Comparative Literature. New York: Pegasus.

[5] Macnicol, N. (1916). "Hindu Devotional Mysticism. International Review of Mission", 5(2), 210-222. doi:10.1111/j.17586631.1916.tb03493.x

[6] Mīnāsiyān, A. K., \& H. (1995). A Companion to Hafez Poems: One-Hundred Ghazal. Tehran Publication.

[7] Prawer, S. S. (1973). Comparative Literary Studies: An Introduction. London: Duckworth.

[8] Samantaray, S. (2013). "Demystifying Mysticism: A Comparative Study of the Poetry of William Blake and Rabindranath Tagore", 3L: The Southeast Asian Journal of English Language Studies, Vol 19(2): 41-51. 
[9] Schimmel, A. (2017, November 22). Sufism. Retrieved March 03, 2018, from https://www.britannica.com/topic/Sufism.

[10] Spurgeon, C. F. (2011). Mysticism in English Literature. Cambridge: Cambridge Univ. Press.

Muhammad Hussein Oroskhan is currently a $\mathrm{PhD}$ candidate at Shiraz University. He has already published a couple of articles in Persian Literature. His main field of interest includes Comparative literature and film studies. He is a lecturer at Yazd University. 